\begin{tabular}{l} 
2. To: (Receiving Organization) \\
Characterization \\
\hline $\begin{array}{l}\text { 5. Proj./Prog./Dept./Div: } \\
\text { Characterization }\end{array}$
\end{tabular}

8. Originator Remarks:

Transmitted for approval and release.
4. Related EDT No.:

Characterization Engineering

6. Design Authority/Design Agent/Cog. Engr.:

G. P. Janicek/R. N. Dale

N/A

7. Purchase Order No.:

$\mathrm{N} / \mathrm{A}$

9. Equip./Component No.:

$\mathrm{N} / \mathrm{A}$

10. System/Bldg./Facility:

2006

12. Major Assm. Dwg. No.

11. Receiver Remarks: 11A. Design Baseline Document? $\bigcirc$ Yes $\bigcirc$ No

$\mathrm{N} / \mathrm{A}$

13. Permit/Permit Application No.:

$\mathrm{N} / \mathrm{A}$

14. Required Response Date:

$\mathrm{N} / \mathrm{A}$

\begin{tabular}{|c|c|c|c|c|c|c|c|c|}
\hline 15. & & DATA TR & NSMITTE & & (F) & (G) & (H) & (1) \\
\hline $\begin{array}{l}\text { (A) } \\
\text { Item } \\
\text { No. }\end{array}$ & (B) Document/Drawing No. & $\begin{array}{l}\text { (C) Sheet } \\
\text { No. }\end{array}$ & (D) Rev. & (E) Title or Description of Data Transmitted & $\begin{array}{l}\text { Approval } \\
\text { Desig- } \\
\text { nator }\end{array}$ & $\begin{array}{c}\text { Reason } \\
\text { for Trans- } \\
\text { mittal }\end{array}$ & $\begin{array}{l}\text { Origi- } \\
\text { nator } \\
\text { Dispo- } \\
\text { stion }\end{array}$ & $\begin{array}{l}\text { Receiv- } \\
\text { er } \\
\text { Dispo- } \\
\text { sition }\end{array}$ \\
\hline 1 & $\mathrm{HNE}-3740$ & ALL & 0 & ENGINEERING TASK PLAN & SQ & 1 & 1 & 1 \\
\hline & & & & & & & & \\
\hline & & & & & & & & \\
\hline & & & & & & & & \\
\hline & & & & & & & & \\
\hline & & & & & & & & \\
\hline & & & & & & & & \\
\hline & & & & KEY & & & & \\
\hline
\end{tabular}

Reason for Transmittal (G)

4. Review

5. Post-Review

6. Dist. (Receipt Acknow. Required)
Disposition (H) \& (I)

1. Approved

2. Approved w/comment

3. Disapproved w/comment

4 Reviewed no/comment

5. Reviewed w/comment

6. Receipt acknowledged

SIGNATURE/DISTRIBUTION
(See Approval Designator for required signatures)

17.

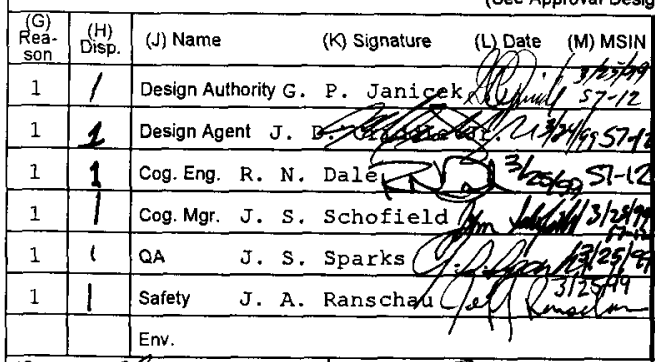

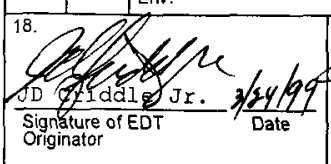

RM Boger $\sum_{2 a} 3 / 2599$
Authorized Reprefentative for Receiving Os sanization

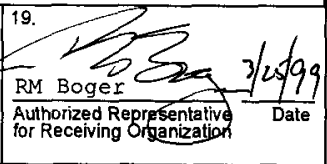

20.

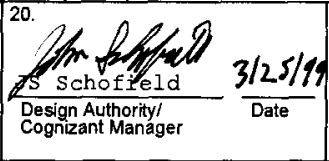

(K) Signature

(L) Date

(M) MSIN $\begin{array}{ll}\text { (H) } & \text { (J) Name }\end{array}$ J. L. Smalley $Y \&$ boully $3 / 25 / 99$ 57-12
21. DOE APPROVAL (if required)

Ctrl No.

Approved

Approved w/comments

Disapproved w/comments 


\title{
ENGINEERING TASK PLAN FOR THE ANNUAL REVISION OF THE ROTARY MODE CORE SAMPLING SYSTEM SAFETY EQUIPMENT LIST
}

\author{
R. M. Boger \\ Prepared by Lockheed Martin Hanford Corp. \\ Richland, WA 99352 \\ U.S. Department of Energy Contract DE-AC06-96RL13200 \\ EDT/ECN: 623365 \\ UC: 2070 \\ Org Code: 74900 \\ Charge Code: 102248 \\ B\&R Code: EW3120074 \\ Total Pages: 12
}

Key Words: Rotary Mode Core Sampling, Safety Equipment List, Design Compliance Matrix, SEL, DCM, RMCS

Abstract: This Engineering Task Plan addresses an effort to provide an update to the RMCS systems 3 and 4 SEL and DCM in order to incorporate the changes to the authorization basis implemented by HNE-SD-WM-BIO-001, Rev. 0 (Draft), Addendum 5, Safety Analysis for Rotary Mode Core Sampling. Responsibilities, task description, cost estimate, and schedule are presented.

TRADEMARK DISCLAIMER. Reference herein to any specific commercial product, process, or service by trade name, trademark, manufacturer, or otherwise, does not necessarily constitute or imply its endorsement, recommendation, or favoring by the United States Government or any agency thereof or its contractors or subcontractors.

Printed in the United States of America. To obtain copies of this document, contact: Document Control Services, P.O. Box 950, Mailstop H6-08, Richland WA 99352, Phone (509) 372-2420; Fax (509) 376-4989.
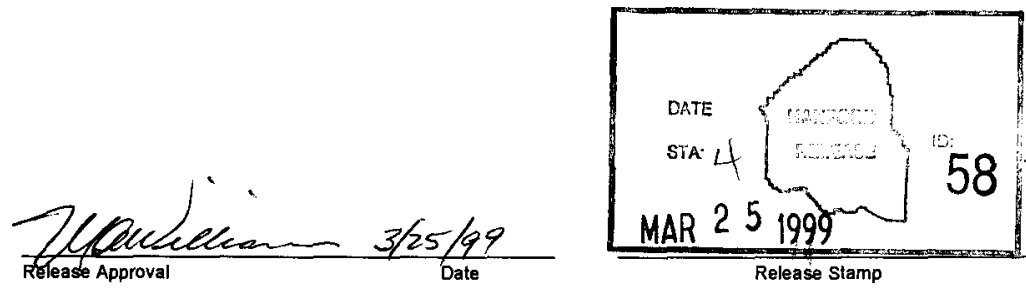

Approved For Public Release 
HNF-3740, REV. 0

\section{ENGINEERING TASK PLAN \\ FOR THE ANNUAL REVISION OF THE \\ ROTARY MODE CORE SAMPLING SYSTEM \\ SAFETY EQUIPMENT LIST}

Prepared for

Characterization Engineering

Lockheed Martin Hanford Corp.

by

J. D. Criddle Jr.

COGEMA Engineering Corporation

March 24, 1999 


\section{TABLE OF CONTENTS}

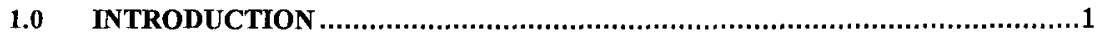

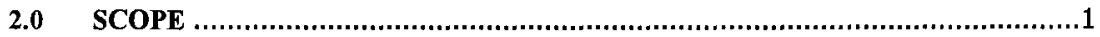

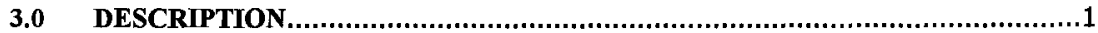

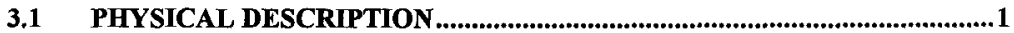

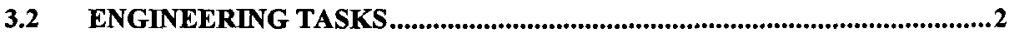

3.3 VERIFICATION, TECHNICAL REVIEWS AND MODIFICATION

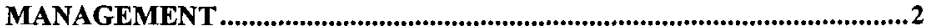

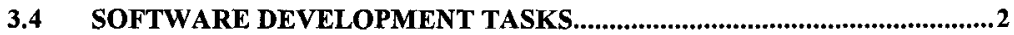

3.5 PROCUREMENT/FABRICATION TASKS.....................................................2

3.6 INSTALLATION/REMOVAL TASKS..........................................................2

3.7 PRE-OPERATIONAL AND OPERATIONAL TESTS (TEST AND

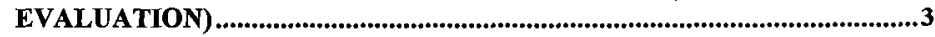

3.8 ACCEPTANCE FOR BENEFICIAL USE (ABU),............................................

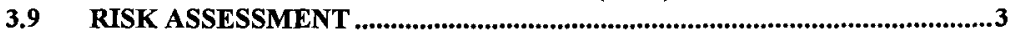

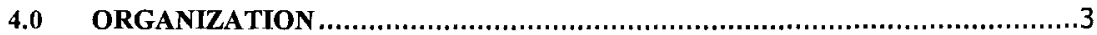

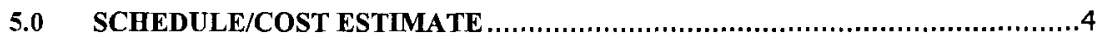

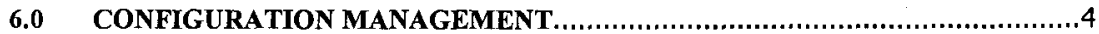

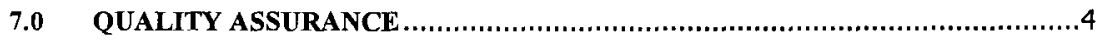

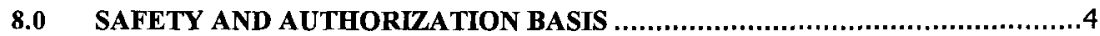

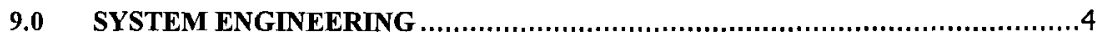

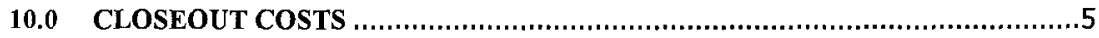

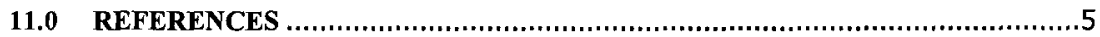

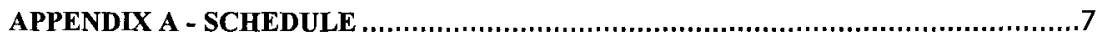




\subsection{INTRODUCTION}

The safety assessment WHC-SD-SAD-035, REV. Oa, (WHC 1996), was authorized in August 1996 per letter 96-QSH-042, (Wagoner 1996). Letter 97-WSD-165, (Wagoner 1997), approved an Authorization Basis (AB) change request. This change to the Rotary Mode Core Sampling (RMCS) System AB was issued by Engineering Change Notice (ECN) 173679, August 8, 1997. This ECN replaced the flammable gas controls contained in WHC-SD-SAD-035, REV. 0a, (WHC 1996), with the controls contained in Standing Order 97-01, Justification for Continued Operation (JCO), and the Basis for Interim Operation (BIO), HNF-SD-WM-BIO-001, REV. 0A, (HNF 1997a). As a result, WHC-SD-WM-SAD-O35, Rev. Ob, (WHC 1997a), WHC-SDWM-0SR-005, Rev. 0-G, (WHC 97B), HNF-SD-WM-BIO-001, Rev. 0-A (HNF 1997a), and HNF-SD-WM-TSR-006, Rev. 0-A, (HNF 1997b) were issued. At this time, it would have been acceptable to update the RMCS Safety Equipment List (SEL) HNF-SD-WM-SEL-044, Rev. 0, (HNF 1997c) to incorporate the philosophy of the $\mathrm{AB}$ regarding the flammable gas controls. However, since the existing SEL was considered conservative, and a unified philosophy regarding the treatment of equipment with relation to the flammable gas controls had not yet been developed, a decision was made not to update the SEL at this time.

In October of 1998, Addendum 5, HNF-SD-WM-BIO-001, Rev. 1-A (Draft), (HNF 1998a), was submitted for review and approval. This addendum will merge WHC-SD-WM-SAD-O35, Rev. Ob, (WHC 1997a) with HNF-SD-WM-BIO-001, Rev. 0-A, (HNF 1997a), or current revision. As a result of this reconciliation, the SEL HNF-SD-WM-SEL-044, Rev. 2, (HNF 1998b) and the design compliance matrix (DCM) HNF-SD-WM-CR-062, Rev. 1, (HNF1998c) will be updated. This update will at a minimum include changes required to reflect the new philosophy regarding the treatment of equipment with relation to the flammable gas controls discussed above. In addition, it will include any modifications required by the approval of Addendum 5, HNF-SDWM-BIO-001, Rev. 1-A (Draft) (HNF 1998a).

\subsection{SCOPE}

The scope of this task is to provide an update to the RMCS Systems \#3 and \#4 SEL and DCM consistent with the changes to the authorization basis implemented by ECN 173679, August 8, 1997 and any additional modifications required by the approval of Addendum 5, HNF-SD-WMBIO-001, Rev. 1-A (Draft) (HNF 1998a).

\subsection{DESCRIPTION}

\subsection{PHYSICAL DESCRIPTION}

This task does not include any modification of RMCS Systems 3 and 4. It is only an update of existing documents. However, an evaluation will be performed to identify any possible equipment changes resulting from the approval of Addendum 5, HNF-SD-WM-BIO-001, Rev. 1-A (Draft) (HNF 1998a). One equipment modification is anticipated and is described in HNF-3663, (HNF 1999). 


\subsection{ENGINEERING TASKS}

The engineering tasks addressed by this plan are to update current safety and design criteria documentation for RMCS Trucks \#3, and \#4. The following is required in order to complete this effort:

- Evaluate HNF-SD-WM-SEL-044, Rev. 2, (HNF 1998b) with respect to Addendum 5, HNF-SD-WM-BIO-001, Rev. 1-A (Draft) (HNF 1998a).

- Update and release HNF-SD-WM-SEL-044, Rev. 2, (HNF 1998b) to incorporate any changes necessitated by ECN 173679, August 8, 1997 and any additional modifications required by the approval of Addendum 5, HNF-SD-WM-BIO-001, Rev. 1-A (Draft) (HNF 1998a).

- Evaluate HNF-SD-WM-CR-062, Rev. 1, (1998c) with respect to Addendum 5, HNFSD-WM-BIO-001, Rev. 1-A (Draft) (HNF 1998a).

- Update and release HNF-SD-WM-CR-062, Rev. 1, (1998c) to incorporate any changes necessitated by ECN 173679, August 8, 1997 and any additional modifications required by the approval of Addendum 5, HNF-SD-WM-BIO-001, Rev. 1-A (Draft) (HNF 1998a).

These Engineering tasks are being performed on behalf of the Characterization Engineering Design Authority (DA), responsible for the preparation and technical content of the documents being revised. A close working relationship with the DA is necessary and will be maintained during the performance of these engineering tasks.

\subsection{VERIFICATION, TECHNICAL REVIEWS AND MODIFICATION MANAGEMENT}

There are no modifications to RMCS Trucks \#3 and \#4 systems included in the scope of this task. This task revises the SEL and DCM documents, which govern the safety classification and design requirements for RMCS Truck systems \#3 and \#4. Revision of these documents will be in accordance with HNF-IP-0842, Vol. IV, Sec. 5.2, (HNF 1998d) and PI-CP-008-00, Rev. 0, (PI 1997) respectively. All updated documents will be reviewed and/or approved by individuals identified in Section 4.0, or as otherwise designated by the Design Authority.

\subsection{SOFTWARE DEVELOPMENT TASKS}

There are no software development activities included in the scope of this task.

\subsection{PROCUREMENT/FABRICATION TASKS}

There are no procurement or fabrication activities included in the scope of this task.

\subsection{INSTALLATION/REMOVAL TASKS}

There are no installation or removal activities included in the scope of this task. 


\subsection{PRE-OPERATIONAL AND OPERATIONAL TESTS (TEST AND EVALUATION)}

There are no testing activities included in the scope of this task.

\subsection{ACCEPTANCE FOR BENEFICIAL USE (ABU)}

There is no ABU preparation or revision associated with this task.

\subsection{RISK ASSESSMENT}

Failure to complete this task would create a situation in which portions of the safety and design criteria documentation for the RMCS Systems 3 and 4 not consistent with the current authorization basis for these systems. This task is starting based on Addendum 5, HNF-SD-WMBIO-001, Rev. 1-A (Draft), (HNF 1998a), which has not yet been approved. Changes to Addendum 5 may require additional change to the SEL and DCM.

\subsection{ORGANIZATION}

The following organizations/individuals will provide support for revision, review, and release of the SEL and DCM updates provided by this task.

Characterization Project Engineering

Manager- RM Boger

Project Manager - JL Smalley

Design Authority- GP Janicek

Responsible Engineer - JD Criddle Jr.

Characterization Field Engineering

Cognizant Manager - JS Schofield

Cognizant Engineer - RN Dale

Characterization Project Operations

Truck Sampling - JS Lee

Technical Operations - JE Corbett

Characterization Support Organizations

Safety - JA Ranschau

Quality Assurance - JS SPARKS

Environmental Ops Compliance - DL Dyekman

Nuclear Safety and Licensing - TG Goetz 


\subsection{SCHEDULE/COST ESTIMATE}

\section{SCHEDULE}

This activity is currently being tracked on the Characterization Equipment Engineering Projects Master Schedule attached in Appendix A. The following assumptions were made in the creation of the schedule:

1. Revision of the SEL and DCM will proceed as scheduled.

2. The revisions can not be officially released until Addendum 5 is approved.

\section{COST ESTIMATE}

ETP Preparation -

$\$ 3,500$

SEL Revision - $\quad \$ 17,500$

DCM Revision - $\$ \$ 14,600$

Total -

$\$ 35,600$

\subsection{CONFIGURATION MANAGEMENT}

The following policies, practices and procedures will be used to govern configuration management during this task.

HNF-IP-0842 Tank Waste Remediation System (TWRS) Administrative Procedures

HNF-PRO-261

Quality Assurance Program Plans

HNF-PRO-440

Engineering Document Change Control Requirements

HNF-PRO-445

Design Verification Requirements

\subsection{QUALITY ASSURANCE}

The existing TWRS QA procedures and requirements shall be followed.

\subsection{SAFETY AND AUTHORIZATION BASIS}

There are no modifications to the safety or authorization basis as a result of this task. This task updates existing safety and design documentation to reflect recent changes in the authorization basis documentation.

\subsection{SYSTEM ENGINEERING}

This task is identified in HNF-SP-1230, (Draft), (HNF 1998e), and funded in WBS \# 1.1.1.1.1.3.1.7. 
HNF-3740, REV. 0

\subsection{CLOSEOUT COSTS}

Should the funding for this task be deleted the closeout costs would be minimal due to the limited scope of the task.

\subsection{REFERENCES}

HNF, 1997a, Tank Waste Remediation System Basis for Interim Operation, HNF-SD-WM-BIO001, Rev. 0-A, Duke Engineering and Services Hanford, Richland, Washington.

HNF, 1997b, Tank Waste Remediation System Technical Safety Requirements, HNF-SD-WMTSR-006, Rev. 0-A, Duke Engineering and Services Hanford, Richland, Washington.

HNF, 1997c, A Safety Equipment List for Rotary Mode Core Sampling Systems Operation in Single Shell Flammable Gas Tanks, HNF-SD-WM-SEL-044, Rev. 0, COGEMA Engineering Corporation, Richland, Washington.

HNF, 1998a, Addendum 5, Safety Analysis for Rotary Mode Core Sampling, HNF-SD-WMBIO-001, Rev. 0 (Draft), Duke Engineering and Services Hanford, Richland, Washington.

HNF, 1998b A Safety Equipment List for Rotary Mode Core Sampling Systems Operation in Single Shell Flammable Gas Tanks, HNF-SD-WM-SEL-044, Rev. 2, COGEMA Engineering Corporation, Richland, Washington.

HNF, 1998c Baseline Design Compliance Matrix for the Rotary Mode Core Sampling (RMCS) System, Tanks, HNF-SD-WM-CR-062, Rev. 1, COGEMA Engineering Corporation, Richland, Washington.

HNF, 1998d Safety Equipment Lists, HNF-IP-0842, Vol. IV, Section 5.2, Rev. 1b, Lockheed Martin Hanford Company, Richland, Washington.

HNF, 1998e Tank Waste Remediation System Fiscal Year 1999 Multi-Year Work Plan WBS 1.I, HNF-SP-1230, (Draft).

HNF, $1998 \mathrm{f}$ Quality Assurance Program Plan, HNF-IP-0842, Vol. XI, Section 1.1, Rev. 0b, Lockheed Martin Hanford Company, Richland, Washington.

HNF, 1998g Tank Waste Remediation System Characterization Project Quality Policies, HNFSD-WM-QAPP-025, Rev. 4, Lockheed Martin Hanford Company, Richland, Washington.

HNF, 1999 Engineering Task Plan for Rotary Mode Core Sampling Exhausters CAM High Radiation Interlock, HNF-3663, Rev. 0, Lockheed Martin Hanford Company, Richland, Washington.

PI, 1997, Design Compliance Matrix, Desk Instruction, PI-CP-008-00, Rev. 0, Characterization Engineering Projects, Lockheed Martin Hanford Company, Richland, Washington. 
Wagoner, J. D., 1996, Authorization of the Safety Assessment (SA) of Rotary Mode Core Sampling (RMCS) in Flammable Gas Single-Shell Tanks, WHC-SD-SAD-035, Rev. 0a and Interim Operational Safety Requirements (IOSR), (letter 96-QSH-042 to A. L. Trego, August 1996), United States Department of Energy-Richland Operations Office, Richland, Washington.

Wagoner, J. D., 1997, Contract number DE-AC06-96RL13200 - Approval of Rotary Mode Core Sampling (RMCS) Authorization Basis Change Request, (letter 97-WSD-165 to H. J. Hatch, July, 1997), United States Department of Energy-Richland Operations Office, Richland, Washington.

WHC, 1994, Rotary Mode Core Sampling Safety Equipment List, WHC-SD-WM-SEL-032, Rev. 1, Westinghouse Hanford Company, Richland, Washington.

WHC, 1996, A Safety Assessment of Rotary Mode Core Sampling in Flammable Gas Single Shell Tanks: Hanford Site, Richland, Washington, WHC-SD-SAD-035, REV. 0a, Lockheed Martin Hanford Company, Richland, Washington.

WHC, 1997a, A Safety Assessment of Rotary Mode Core Sampling in Flammable Gas Single Shell Tanks: Hanford Site, Richland, Washington, WHC-SD-WM-SAD-035, Rev. 0b, Lockheed Martin Hanford Company, Richland, Washington.

WHC, 1997b, WHC-SD-WM-OSR-005, Rev. 0-G, Single Shell Tank Interim Operational Safety Requirements, Duke Engineering and Services Hanford, Richland, Washington. 


\section{APPENDIX A - SCHEDULE}




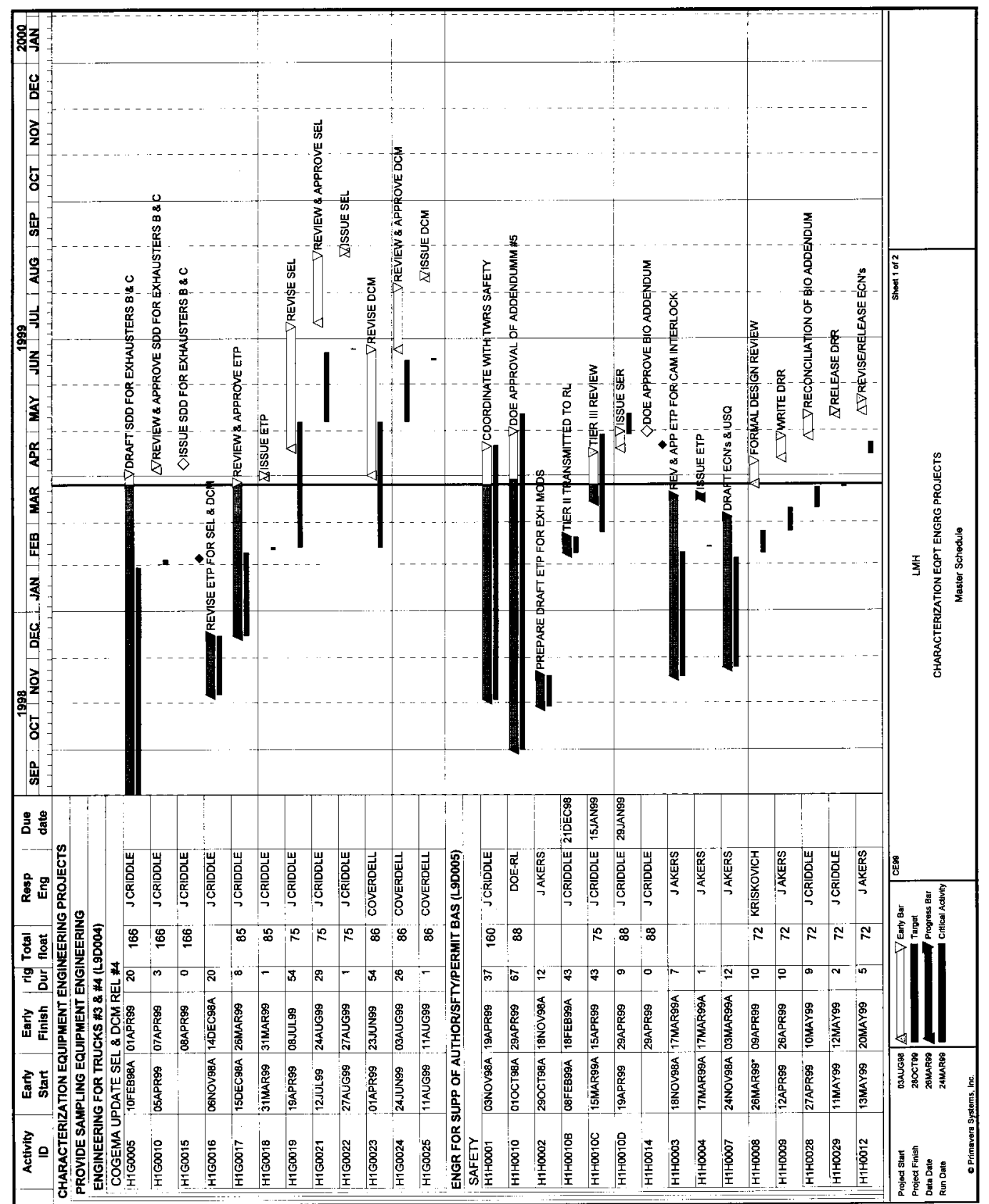




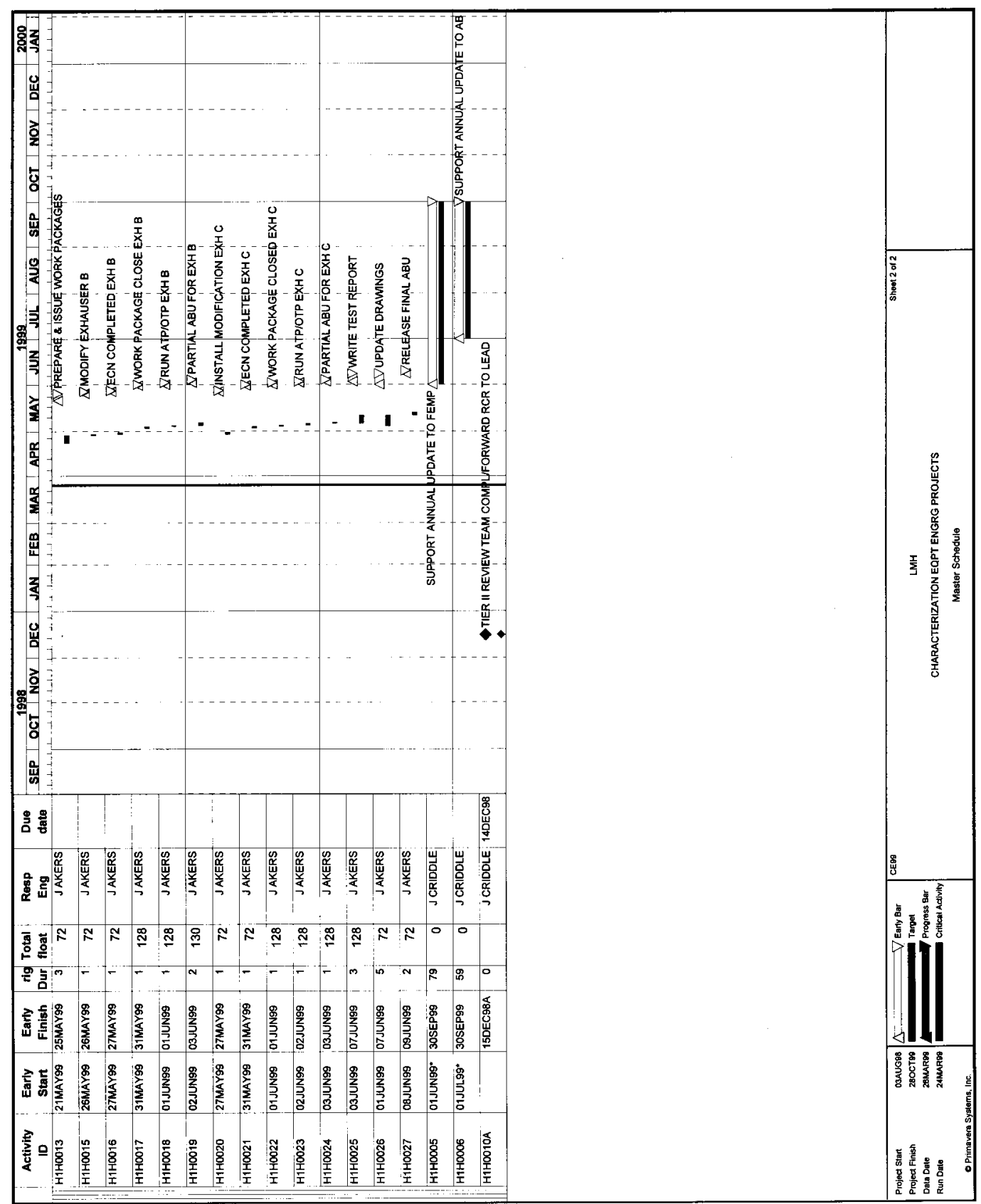




\section{DISTRIBUTION SHEET}

To

Distribution

Project TitleMork Order

HNF-3740 ENGINEERING TASK PLAN FOR THE ANNUAL REVISION OF THE ROTARY MODE CORE SAMPLING SYSTEM SAFETY EQUIPMENT LIST

\begin{tabular}{|l|l|}
\hline \multicolumn{1}{|c|}{ Name } & \\
\hline JC AKERS & \\
\hline JD CRIDDLE Jr. & \\
\hline RM BOGER & \\
\hline BL COVERDELL & \\
\hline RN DALE & \\
\hline GP JANICEK & \\
\hline RW MATTICHAK & \\
\hline JA RANSCHAU & \\
\hline JS SCHOFIELD & \\
\hline JL SMALLEY & \\
\hline JS SPARKS & \\
\hline
\end{tabular}

From
JD Criddle Jr. s7-12

S7-12

s7-12

s7-12

$57-12$

S7-12

S7-12

57-07

57-12

57-12

57-07

$\mathrm{x}$

$x$

$\mathrm{x}$

$\mathrm{x}$

$\mathrm{x}$

$\mathrm{x}$

$\mathrm{x}$

$x$

$x$

$x$

$\mathrm{x}$

\begin{tabular}{l} 
Page 1 of 1 \\
Date $3 / 25 / 99$ \\
\hline EDT No. 623365 \\
\hline ECN No. \\
\hline
\end{tabular}

\begin{tabular}{|c|c|c|c|c|}
\hline MSIN & $\begin{array}{c}\text { Text } \\
\text { With All } \\
\text { Attach. }\end{array}$ & Text Only & $\begin{array}{l}\text { Attach./ } \\
\text { Appendix } \\
\text { Only }\end{array}$ & $\begin{array}{c}\text { EDT/ECN } \\
\text { Only }\end{array}$ \\
\hline
\end{tabular}

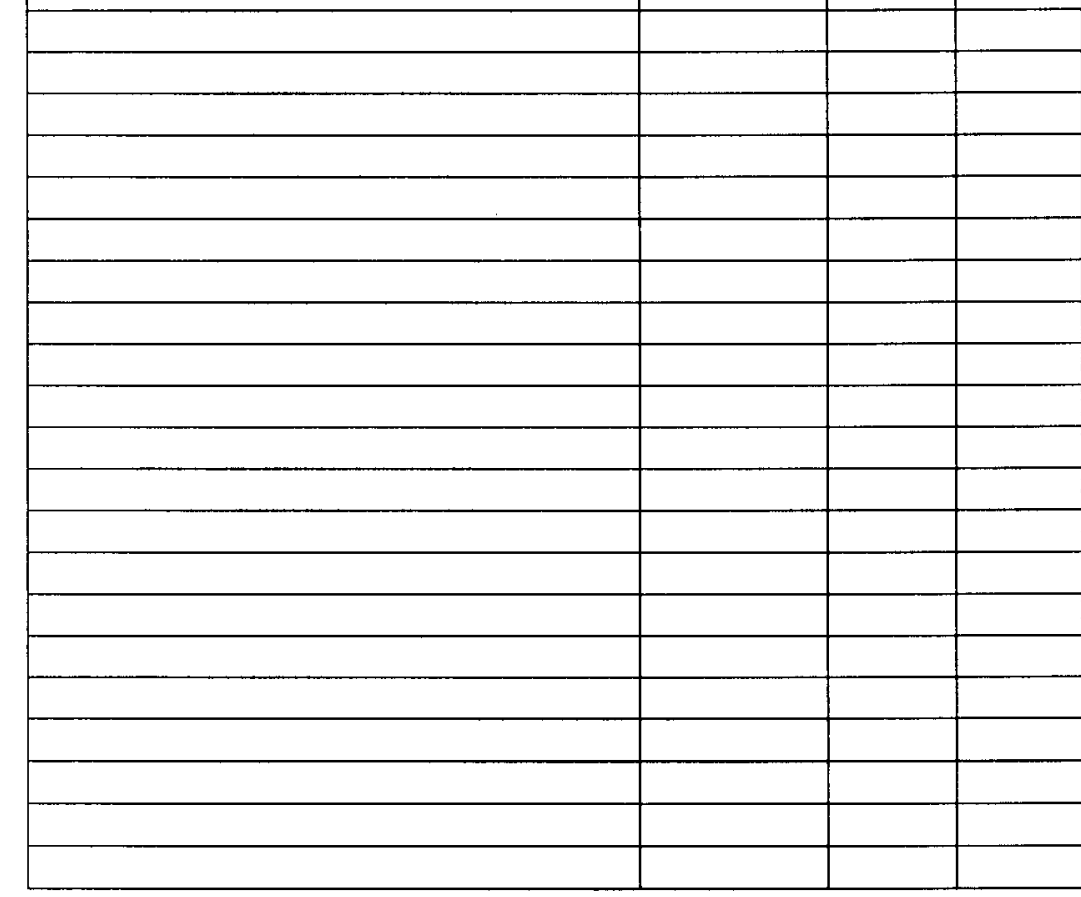

